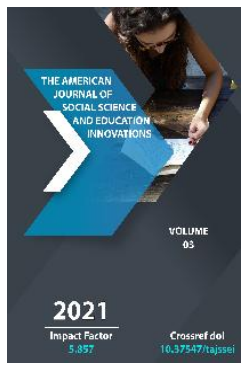

\section{Important Aspects Of The Integration Of The National Idea Into The Minds Of Young People In The Era Of Global Changes}

\author{
Tashmetov Tuxtasin Xudoyberganovich \\ Tashkent Region Chirchiq State Pedagogical Institute Teacher Of The Department" Social \\ Sciences", Uzbekistan
}

Journal Website:

http://theamericanjour nals.com/index.php/taj ssei

Copyright: Original content from this work may be used under the terms of the creative commons attributes 4.0 licence.

\title{
ABSTRACT
}

In the era of today's global changes, it is necessary to have a deeper understanding of each essence of the social phenomenon, a comprehensive study of its features. Bunda serves as a national idea nationwide program. After all, in the period of global changes, it is necessary to integrate the National idea into the consciousness, soul and inner world of young people on the basis of innovative technologies, to educate them in the spirit of loyalty to the native land, to further form initiative, self - sacrifice, moral qualities in them - to become an extremely honorable task on the basis Only then, in the future, we will achieve the upbringing of a spiritually harmonious person, a healthy generation. One of the priority tasks of our society is also an expression from the upbringing of a harmonious generation. After all, only people of spiritual perfection can create a great future.

\section{KEYWORDS}

Global, technology, national idea, culture, enlightenment, modernization, innovation, internet, civilization, ideology, democracy, individualism, egocentrism, information attacks, communication.

\section{INTRODUCTION}

Today's humanity lives in a historical period that is changing in rapid pictures, which is very fast, severe and fully manifests all the complexities that have been experienced to this day, radically different from the stages of society. In the following years, such words as "the globalizing world", "global society", "global integration"," global development " did not fall from the language. Mankind is faced with a new reality - a period of global changes, trying to understand it, to ensure its development using positive aspects in it productively. But it is still too early to consider 
global change as only a positive reality, it is full of contradictions, and goho has signs that negatively affect national development, National Culture, National idea. As First President Islam Karimov pointed out: "today we are living in an extremely violent and difficult time that is rapidly changing, radically different from the Times that humanity has experienced so far. State and political figures, philosophers and sociologists, commentators and journalists describe this period in different ways and say it with different names. Someone interprets it as a period of high technology, someone interprets it as a period of contemplation, someone else's period of gross information.

Of course, even in all these thoughts there is a certain sense of truth, a rational core. Because in each of them it is natural to reflect in itself some kind of sign - sign of today's multifaceted and colorful life. However, in the minds of many, this period evokes the impression that the era of globalisation"[1]. In fact, today globalism is a historical evolutionary continuation of the development of mankind, a real reality that has arisen as a new stage.

Globalisation is the interconnection, interconnection of the growing social, political, and economic and other relations of all countries, territories and entire continents around the world. In other words, globalism is a process of further increasing the interdependence of the development of all nations, societies. It is also studied as a phenomenon that strongly influences the culture of peoples. In this regard, the researcher N.Umarova writes: "globalism is a gross, lexical nature profession, its impact on the sphere of information, spiritual life, politics, economy, social spheres, as negative aspects of globalism in these areas, it brings social phenomena such as cultural hegemony, Euro-centrism, consciousness management manipoliation."[2] therefore, the greatest danger in the present day is the continuing ideological struggle to capture the hearts and minds of people. Now the struggles that are happening not in the nuclear arena, but in the fields of ideology, solve a lot of things. This bitter truth should never be forgotten.[3] the threats in the guise of democracy are consciously carried out by various political forces in the international arena.[4] indeed, in the current era of global changes in all spheres of social life, the scale of spiritual threats is also accelerating. As a result, the spiritual threats that affect the culture of the nation are bringing new challenges to humanity. Our resistance to these spiritual and ideological threats coming from abroad, poisoning the citizens of our country, especially the youth consciousness and the inner world with the ideas of individualism, moral corruption, violence, egocentrism, is a requirement of today's era.

Therefore, in such conditions, every nation seeks to ensure the security of its national values, not to deviate from its historical foundations and not fall under the influence of other people. It is becoming more and more important that states can protect their interests in the global information Arena and counter various information attacks. In such circumstances, the information factor is of paramount importance in protecting our national interests. In this sense, it requires maintaining a strong information policy aimed at protecting our national values. This means that the use of modern technologies in information delivery has become one of the pressing issues of the present. In particular, only by observing global changes in the sphere of information and communication, we can see that its impact is becoming the main weapon for ideological and cultural hegemony in the world. And the countries that have risen in Information Technology are the driving forces of this process. In particular, through mass media communications, misinterpreting various events, or slightly falsifying, bridge opposes the entire world community to a particular state, including some of the citizens 
of that state. Political opposition attempts to raise different groups of mercenaries, sometimes even extremist and radical religious groups, to the level of political opposition in countries that are not well developed. Western countries have given shelter to the leaders of such groups, using them in their mercenary geopolitical games, in the consciousness of the inhabitants of a particular country.

Continue our thinking, if we focus on the meaning of the term is an act of influencing people, skillfully managing them, in particular, looking at them as an object, being in a careless attitude, hidden management or processing. "ulyulation (lot. Monolus-hand movement) - achieve a merciless goal through maximization, deception, extortion, fraud"[5]. Manipulation is not violence, it is a temptation that causes admiration for something in a person, a way to mislead him. In this regard, life itself proves that the contradictions associated with global changes are evident, especially in the National idea and spiritual sphere. Therefore, by modernizing the life of society, it is of paramount importance to develop further the tasks that must be carried out in the National idea and spiritual sphere.

To do this, in the conditions of modernization of the life of society, we must perform the following functions in the National idea and spiritual sphere::

- Transforming our youth into an active participant in the process of spiritual renewal and reform;

- Ideas that harmonize the specific desires and aspirations of young people with different views and opinions, the prosperity of Vatan, the peace of the country, the well-being of the people, a perfect person, a unique sense of Vatan, justice-in the rule of law, people's consent, Enlightenment against ignorance, ensuring innovative development, achieving the transformation of the sacred goal for all;

- Continuing to work on clarifying the humanistic essence of the religion of our ancestors to the general public.

- To do this, first:

- To present mass demonstrations, serials, film and feature films, which reflect our national spirituality in the media, to the public attention;

- To increase the number of national sites using the internet system and to ensure the integration of young people and national ideas through them;

- It is also necessary to introduce scientific projects on the topic of improving national ideas and spirituality in society and to ensure the rule of law in the use[6].

At the same time, the issue of integrating the basic concepts and principles of our national idea into the minds and hearts of our people is also one of the important tasks. Constant raising the spiritual and educational level of the population, especially young men and girls in our society - is of primary importance. Therefore, the education of young people in the spirit of loyalty to the native land, the formation of initiative, self - sacrifice, moral qualities on the basis of the program idea" from the national revival - towards the national rise " - has become a very honorable task[7]. In particular, the study of the various events taking place in society through the integration of national idea and spirituality into the consciousness, soul and inner world of young people and the correct attitude to them, preservation of national and spiritual values, and teaching them to contribute to the development of society are also important tasks. From this point of view, since the future of any state is in the hands of young people, it is also necessary to start the measure of protection, first of all, by absorbing the spirit of nationality into the minds of the younger generation. Only then will we be able to educate a healthy generation that is spiritually harmonious in the future. After all, this is one 
of the priorities of Public Policy. In this regard, the president of the Republic of Uzbekistan Sh.M.As Mirziyoyev noted: "We will continue our state policy towards young people without any deviations and resolutely. Not only will we continue, but as a priority task of this policy, we will raise it to a high level that is in demand today. We will mobilize all the forces and opportunities of our state and society to ensure that our young people are independent-minded, have a high spiritual and spiritual potential, grow up to their peers on a global scale as people who are not idle in any sphere, be happy"[8] if necessary, we are able to strike sharply against any attempts that threaten the sovereignty Indeed, from the opportunities that the globe is creating, political and ideological centers that are currently trying to fill the spiritual gap are used. It should be noted that as a result of this, great spiritual losses by mankind, the century-old values of the nation, national thinking and lifestyle are being undermined, morality, family and community life, conscious lifestyle are endangered.

It is known that in the period of global changes, the integration of the National idea into the consciousness, soul and inner world of young people through the Universal Princeps of democracy is carried out through the following circumstances. 1) the noble idea and goal should become a belief in the consciousness and thinking of each person, that is, it is necessary to believe in him; 2) a person has the ability, skill to apply the noble ideas and goals he believes in in his life, to apply to him his life goal, to become an integral part of the way of life; 3) that the socialization of members of a particular social group, stratum, Ethnos, people, nation, society at the level of consciousness and contemplation has become an idea; 4) the transformation of the goals of a national idea into a unified ideology means it to serve together, harmoniously in the same way, in the same way, to work for the realization of a common goal, it is means a feeling.
In this place, we are far from denying the progress achieved by the progressive humanity, the universal human values that serve the development of our nation, and the principles of democracy. We just want to condemn the need to harmonize our national traditions and traditions with universal values, which have been polished for centuries. To be more precise, the principles of democracy should not be taken into account as a rejection of our national values, but rather as a service to their further improvement and prosperity. In addition, not only promoting the centuries-old spiritual and educational heritage, customs and traditions of our people, studying the values and family traditions of other nationalities, analyzing the positive and negative changes taking place in the National ideas and spirituality of other nations, it also provides the ground for further strengthening the economic, social and spiritual foundations of the Family Institute would have created.

Speaking about the main factor and reason for the rapid and deep penetration of the battalion into our lives of Global changes, one must admit that today the development and prosperity of any state is so closely connected not only with the near and far troops, but also with other regions and territories on a global scale, it is not difficult to understand that Globalism is a weather, natural-historical process that expresses the internal needs of human civilization development[10].

In fact, in the period of global changes, the high morale of people is an important factor in the Prevention of moral and ideological threats that undermine the national culture of the country. To do this, it is necessary to organize spiritual and ideological work in society on the basis of modern requirements. That is, first, to protect young people who are the future of the country from various ideological threats; second, to comprehensively understand exactly what the spiritual threats are aimed at; third, to further 
increase the sense of genius, without being indifferent to the events that are happening around us.

As one of the main tasks facing our society at the moment, the creation of effective ways, methods and means to combat various ideological and spiritual threats is of paramount importance.

As an innovative technology of integrating the National idea into the consciousness, soul and inner world of young people, we recommend:

$>$ The age of faith - belief in further strengthening;

$>$ The inner world and the will to make them energetic;

$>$ Orientation of independent, free thinking and analysis of young people;

$>$ Educating the perfect people and young people;

$>$ Self-awareness, self-recognition, their contempt;

$>$ Achieve survival with pride and pride;

$>$ Decision - making to preserve and respect our sacred values in order to find the virtues of youth;

We will achieve friendship among the peoples of our country and further cooperation[11].

And for this, the only ideology is the development of Uzbekistan, the prosperity of Uzbekistan, the fact that Uzbekistan is no less important than anyone else in the world. This means that when the National idea, the national ideology is absorbed into the consciousness of all of us, our fancy, our thinking, we can build a state of our own dreams, a society with a strong fortitude.

In place of the conclusion, it should be said that in the era of today's global changes, the promotion of the National idea through modern methods to the hearts, minds and inner world of every person, especially young people, is a requirement of the present day for the comprehensive formation of spiritual, moral, educational qualities in them. After all, the development, spirituality and culture of the nation is a link to the highly educated we youth. To do this, in today's renewing society, it is necessary not only to act freely, but also to unite on the basis of a single national idea for its development, but also to prioritize the idea of "restoration of free and prosperous life" and "from the national revival - towards the rise of the National." Only then will we save our youth, and at the same time our people from any evil forces of globalism and a flood of spiritual threats, they will create in their hearts a foundation for a further rise in loyalty to the land, feelings of love for the motherland.

\section{REFERENCES}

1. Karimov I.A. Yuksak ma'naviyat yengilmas kuch. - T.: “Ma'naviyat". 2008 yil, B-110.

2. N.Umarova. Madaniy vasvasa yoxud axloqning globallashuvi // Jamiyat va boshqaruv.- T-№2.-37. B.

3. I.A. Karimov Ozod va obod vatan, erkin va farovon hayot pirovard maqsadimiz. T. O'zbekiston, 2000. B491.

4. X.Ochilov. Demokratiya niqobidagi tahdid. -T. Muharir. 2010.-4-b.

5. Ma'naviyat asosiy tushunchalar izohli lug'ati. -Toshkent: G'ofur G'ulom nashiryoti, 2010. B-278.

6. Berdaliyev N.Sh. "Globallashuv sharoitida axborot tahdidlariga qarshi kurashishning zamonaviy texnologiyalarini yaratish muammolari" mavzusidagi xalqaro ilmiy-amaliy konferentsiya materiallari T:. "Fan va texnologiya" 2020 yil, B129-130

7. O'zbekiston Respublikasi Prezidenti Shavkat Mirziyoyevning Oliy Majlisga Murojaatnomasi. 24 yanvar 2020 yil. https://president.uz/uz/lists/view/3324. 
8. Mirziyoyev Sh.M. Erkin va farovon, demokratik O‘zbekiston davlatini birgalikda barpo etamiz. -T., O'zbekiston: NMIU, 2016. B-14.

9. Mirziyoyev Sh.M. Erkin va farovon, demokratik O‘zbekiston davlatini birgalikda barpo etamiz. -T., O'zbekiston: NMIU, 2016. B-11.

10. Ma'naviyat: asosiy tushunchalar izohli lug'ati. - T.: G'afur G'ulom nomidagi nashriyot-matbaa ijodiy uyi, 2010, B120.

11. Uzokov B. "Globallashuv sharoitida axborot tahdidlariga qarshi kurashishning zamonaviy texnologiyalarini yaratish muammolari" mavzusidagi xalqaro ilmiy-amaliy konferentsiya materiallari T:. “Fan va texnologiya” 2020 yil, B-9394. 